\title{
Ampelographic and Genetic Characterization of Grapevine Varieties (Vitis vinifera L.) of the 'Mavroudia' Group Cultivated in Greece
}

\author{
Maritina STAVRAKAKI*, Katerina BINIARI
}

\author{
Agricultural University of Athens, School of Agriculture, Engineering and Environmental Sciences, Department of Crop Science, Laboratory of \\ Viticulture,Iera Odos 75, 118 55, Athens, Greece; maritina@aua.gr ("correspondingauthor); kbiniari@aua.gr
}

\begin{abstract}
Twenty-one grapevine varieties grown all over Greece and belonging to 'Mavroudia' group were ampelographically described and genotyped by AFLP molecular analysis in order to discriminate the varieties, synonyms, homonyms and variations of the group. In most cases, the molecular findings confirmed the results of the ampelographic description. In general, and despite the high degree of genetic similarity between certain pairs of the studied cultivars, the group of 'Mavroudia' was characterized as being heterogeneous. From the studied cultivars, 'Kountoura mavri', 'Mavro Spetson' and 'Pappoudes' showed very high degree of genetic similarity, sustaining the hypothesis that the last two are clones of the first. Grapevine cultivar 'Pappoudes' was for the first time ampelographically described and identified as being closely related to 'Kountoura mavri'. High degree of genetic similarity was observed between cultivars 'Gaidouricha' and 'Agiomavritiko', suggesting that they probably originated from the same parent variety through the accumulation of mutations. This may also be true for cultivars 'Mavrokorakas' and 'Kartsiotis'. Also, the results from the statistical analysis showed that 'Mavro Arachovis', 'Mavroudi Voulgarias' and 'Voulgaroudes', despite the relatively high genetic similarity between them, are different. The same applies for the rest of the cultivars studied, while 'Mavro Kalavriton', the most widespread variety of the 'Mavroudia' group, showed the lowest degree of genetic similarity within the all the cultivars studied. The ampelographic description in combination with the molecular method AFLP are effective for the study of the between and within genetic diversity of grapevine cultivars as well as for their identification and discrimination.
\end{abstract}

Keywords: AFLP, ampelographic description, genetic diversity, grapevine cultivar, phenotyping

\section{Introduction}

The Greek vineyard is characterized, despite its relatively small size, by varietal richness and by a land area of cultivation that is relatively large (approx. 110000 ha, of which 70000 ha yield wine grapes). There are more than 700 reported varieties of which 280 are included in the National Catalogue of Grapevine Varieties (Ministry of Rural Development and Food, 2015). The large number of synonyms and homonyms as well as the grouping of many varieties under the generic name 'Mavroudia' and 'Asproudia' are among the reasons that make the identification and discrimination of Greek grapevine varieties a difficult task (Stavrakaki and Biniari, 2016).

'Mavroudi' (meaning blackish) also known as 'Mavro' (meaning black) is a generic name that was given to several almost distinct varieties all over Greece which all constitute the group of 'Mavroudia'. In fact, in Greece, there is not one specific variety with the name 'Mavroudi'. The word 'Mavroudi' is often followed by a specific characteristic of the berry ('Mavroudi chondrorago', 'Mavroudi psilorago'), of the must ('Mavrostifo') or the name of the region of origin ('Mavroudi Nemeas', 'Mavroudi' or 'Mavro Arachovis' etc.). Due to this conventional criterion of the color of the skin, many Greek black/red wine grapevine cultivars are included in this large group, and at least until the end of 1970 the most famous among them being 'Agiorgitiko' (aka 'Mavroudi Nemeas', 'Mavro Nemeas'), 'Xinomavro' (aka 'Mavro Naoussas', 'Popolka') and 'Mavrodafni'.

The names 'Mavroudi' and 'Mavroudion' were mentioned by Palaiologos (1836), Poniropoulos (1888), Gennadios (1895) and Viala and Vermorel (1909), but it is not clear whether they were referring to the same cultivar(s). Guillon (1896) describes ampelographically varieties 'Mavron' and 'Mavroudion' as being different. Krimbas (1943) provides a full ampelographic description for variety 'Mavroudi', mentions varieties 'Lianomavroudi' and 'Chondromavroudo' as being variations and notes that the variety is also known as 'Mavro' (Spetses, Argolida), 'Mavraki' (Achaia) and 'Karvouniaris' (Messinia). Later, Krimbas (1944, 1949) describes varieties 'Chondromavroudi', 'Karvouniaris', 'Mavraki' and 'Mavrostifo' as being different. According to Logothetis and Vlachos 
526

(1966), 'Mavroudi' is considered an old Greek variety with different biotypes ('Chondromavroudo', 'Lianomavroudo') and many synonyms ('Karvouniaris', 'Mavraki', 'Mavrostafilo' and 'Mavro'), while later Vlachos (1986) mentions 'Mavro Nemeas', 'Agiorgitiko' as synonyms. Davidis (1967) describes variety 'Mavroudi Thrakis' which shows similarities to grapevine cultivar 'Voulgaroudes' in many ampelographic characters.

In addition to the ampelographic description, in order to discriminate the varieties, synonyms, homonyms and variations of the group of 'Mavroudia', biochemical and molecular methods have been used. The use of biochemical methods (Stavrakakis, 1981, 1990) confirmed the genetic heterogeneity between the varieties studied, while the absence of common electrophoretic bands between these varieties in one or more enzymic systems studied showed that they do not originate from an initial variety through the accumulation of mutations. The genetic heterogeneity between the 'Mavroudia' studied was also confirmed with the use of molecular markers RAPD (Biniari and Stavrakakis, 2013) and SSR (Merkouropoulos et al., 2015). Therefore, the name 'Mavroudi' by itself, without being accompanied by a toponym or other characteristic of the variety, is not enough in order to determine the identity of a variety.

Although the molecular method AFLP has been successfully used for the identification and discrimination of grapevine cultivars and the determination of the degree of genetic similarity between varieties, clones and rootstocks (Vignani et al., 2002; Imazio et al., 2002; Fanizza et al., 2005; Blaich et al., 2007; Stenkamp et al., 2009; Alba et al., 2011; Anhalt et al., 2011; Meneghetti et al., 2012; Shinde et al., 2013), the combined use of the ampelographic description for the selection of the proper sample, especially in the case of heterogeneous groups of grapevine varieties, as is the 'Mavroudia' group, is deemed necessary.

The group of 'Mavroudia' includes varieties that are considered as either closely related, synonyms or homonyms although their name indirectly refers to the characteristic black color of the skin of the berries. For example, grapevine varieties 'Karvouniaris' (from the Greek word karvouno = coal, implying the black color), 'Karabraimis' (from the Turkish word kara = black, and the name Ibrahim), 'Papadiko' (from the black color of the clothing of the Greek priests, papas $=$ priest).

'Agiomavritiko' and 'Gaidouricha' are very old wine cultivars of the Ionian Islands (Corfu, Lefkada) and today they are cultivated sporadically in different regions (Thessaly). Grapevine cultivar 'Agiomavritiko', certainly of polyclonal nature, most likely owes its name to its origin from Lefkada, which was called Agia Mavra during the 14th century. It is mentioned that there is a church of Agia Mavra in the island of Zante as well (in the community Machairado) and that 'Agiomavritiko' originates from this specific region. 'Agiomavritiko' is not registered in the National List of Grapevine Varieties.

Grapevine cultivar 'Gaidouricha' has been described by Krimbas (1943) and it is mentioned as 'Gaidourica' (Pulliat 1888), 'Gaidourica', 'Guadurea' (Guillon, 1896) and 'Gaidouria noir', 'Gaidourica', 'Gaidourcia' (Viala and Vermorel, 1909). The name derives from the Greek word gaidouri $=$ donkey and refers to the high vigor and productivity of its big vines which, just like donkeys, can bear a heavy load (Stavrakaki and Stavrakakis, 2017).

The variety 'Kountoura mavri' constitutes a clone or synonym of grapevine variety 'Mandilaria' (Krimbas, 1944) and the name 'Kountoura' derives from the Turkish word "kundura" [a woman's slipper], due to the shape the vines have after their winter pruning (Stavrakaki and Stavrakakis, 2017). It is mentioned as 'Koundoura' by Viala and Vermorel (1909).

Regarding 'Pappoudes', it is a grapevine cultivar that is being cultivated in multi-varietal vineyards in various viticultural areas. The name derives from the Greek word pappous $=$ grandfather, implying apparently that the variety has been known for a long time.

'Mavrokorakas' is a minor traditional grapevine cultivar grown sporadically in various regions of Greece, mainly in Peloponnese. The name may be attributed to the black color of the skin of the berries which is reminiscent of the bird koraki (in Greek koraki = crow). It has been described by Krimbas (1944) while it is mentioned as 'Korakas' (Viala and Vermorel, 1909). According to Krimbas (1944), the cultivars 'Corbeau' and 'Corbeau nero' which are mentioned by Pulliat (1888) and Molon (1906) respectively, resemble 'Mavrokorakas'.

Grapevine cultivar 'Mavro Kolliniatiko' (synonym 'Evgeniko') is considered the only Greek variety in which anthocyanins occur in the form of 3-5 diglucosides (Harvalia, 1961). Its name may be attributed to its region of origin (Community Kollines of central Peloponnese) (Stavrakakis et al., 2017).

Grapevine cultivar 'Kartsiotis' is cultivated in small surface areas in Thessaly and in the islands of northern Sporades. It is reported that the variety has been cultivated in Skiathos since the 18th century or even earlier under the name 'Korizotis' (Stavrakakis et al., 2017). It is mentioned as 'Kartsotis' (Viala and Vermorel, 1909) and 'Carchiotis' (Guillon, 1896).

'Mavroboubouko' and 'Papadiko' are considered to be indigenous to the Ionian Islands, mainly Zante, where 'Papadiko' is also known as 'Papaditsa'. The name 'Mavroboubouko' probably derives from the words mavro (=black) and mpoumpouki [= the vine bud in the stage C according to Baillod and Baggiolini (1993) system] (Stavrakakis et al., 2017).

Grapevine cultivar 'Mavroliatis' is cultivated in the islands of southern Aegean. It was considered to be a synonym of grapevine cultivar 'Liatiko', but a recent study that employed molecular methods showed that they are different cultivars (Biniari and Stavrakaki, 2016).

'Mavro Kalavriton' is possibly the most widespread variety of the 'Mavroudia' group in the vineyards of Peloponnese. It is of polyclonal synthesis and its most wellknown clone is 'Psilomavro Kalavriton'.

'Mavrostifo' is cultivated in small surface areas in eastern Peloponnese and it is often mentioned as synonym of grapevine cultivar 'Mavro Spetson'. It has been ampelographically described by Krimbas (1944) and it is mentioned as 'Mavrostypha' by Viala and Vermorel (1909). 'Mavrostifo' owes its name to the high skin concentration in tannins (Stavrakakis et al., 2017). 
'Mavrotragano' is an interesting wine grape cultivar of the Cyclades. Its name may be attributed to the very firm flesh of the berries.

'Mavro Siriano' is a minor variety which is cultivated in the island of Syros.

'Vlachiko' is indigenous and the main wine grape cultivar of Epirus. It is a variety of great adaptability to semimountainous and rather cold regions. Its name may most likely be attributed to the Vlachous, but it may also imply its resilience and resistance to harsh soil and weather conditions (vlachos, vlachikos: raw, tough) (Stavrakakis et al., 2017).

Lastly, grapevine cultivar 'Mavroudi Voulgarias' ('Mavrud') was also studied. According to Katerov (2004, in Robinson et al., 2012), 'Mavrud' is indigenous to Bulgaria, with many variants (large-berried, small-berried etc.).

The objective of the present study was the identification and the discrimination of grapevine varieties, synonyms, homonyms and variations of the extremely heterogeneous group under the generic name 'Mavroudia' which are cultivated in Greece using the combination of both the ampelographic description and the molecular method AFLP.

\section{Materials and Methods}

\section{Plantmaterial}

Twenty-one Greek grapevine cultivars (Vitis vinifera L.) belonging to the 'Mavroudia' group were chosen for identification using the ampelographic description and the molecular method AFLP. The studied varieties, the viticultural areas in which their cultivation is recommended or allowed according to the Greek legislation, and the areas from where the samples were collected are presented in detail in Table 1. It should be noted that these cultivars are preserved in the Ampelographic Collection of the Institute of Viticulture
(National Agricultural Research Foundation, NAGREF, Lykovrysi), and in the Ampelographic Collection of the Laboratory of Viticulture (Agricultural University of Athens, AUA).

\section{Ampelographic and molecularmethods}

For the ampelographic description, 29 ampelographic characters were used and measured on each grapevine cultivar during the years 2014, 2015, 2016 following a list of descriptors developed by the International Organization of Vine and Wine (OIV, 2009) including the preliminary minimal traits relative to shoot, mature leave, bunch etc. among others.

The AFLP molecular analysis was conducted as reported by Vos et al. (1995), following the AFLP Plant Mapping Protocol by Applied Biosystems (2007), with several modifications (Stavrakaki and Biniari, 2016). Grapevine DNA was extracted from young and fully expanded leaves according to Thomas et al. (1993), with minor modifications. A total of seven primer combinations with three selective nucleotides and fluorescent dye (in the form of EcoRI[Primer-Axx-Dye] and MseI[PrimerCxx]) were used to amplify genomic DNA through the Polymerase Chain Reaction in order to identify and discriminate the selected cultivars (Table 2).

PCR amplifications were performed in a Perkin Elmer DNA Thermal Cycler 9600 and PCR fragments were separated using capillary electrophoresis on an ABI Prism 310 Genetic Analyzer (Applied Biosystems, USA). Data analysis, sizing and genotyping were performed using the GeneMapper v4.0 software (Applied Biosystems, USA).

\section{Data analysis}

For the statistical analysis, relationships among the OIV descriptors (parameters) were studied using the statistical program JMP (JMP v.10 statistical software, SAS Institute Inc., Cary, NC, USA). Principal Component (PC) analysis was

Table 1. Cultivars studied and sampling areas

\begin{tabular}{|c|c|c|c|c|}
\hline$a / a$ & Cultivar $^{a}$ & Collection $^{b}$ & Berry color $^{c}$ & Growing region $^{\mathrm{d}}$ \\
\hline 1 & Agiomavritiko & $\mathrm{N}$ & B & $\mathrm{I}, \mathrm{Th}$ \\
\hline 2 & Gaidouricha & $\mathrm{N}$ & B & I \\
\hline 3 & Karabraimis & $\mathrm{L}$ & Rs & $\mathrm{C}, \mathrm{S}$ \\
\hline 4 & Kartsiotis & $\mathrm{L}$ & B & $\mathrm{Th}$ \\
\hline 5 & Karvouniaris & $\mathrm{L}$ & B & $\mathrm{P}$ \\
\hline 6 & Kountoura mavri & $\mathrm{L}$ & B & A, C, D, P, S, Th \\
\hline 7 & Mavroboubouko & $\mathrm{N}$ & B & I, P \\
\hline 8 & Mavrokorakas & $\mathrm{L}$ & B & C, I, P \\
\hline 9 & Mavroliatis & $\mathrm{L}$ & B & $\mathrm{C}$ \\
\hline 10 & Mavrostifo & $\mathrm{L}$ & B & I, P \\
\hline 11 & Mavrotragano & $\mathrm{N}$ & B & $\mathrm{C}$ \\
\hline 12 & Mavro Arachovis & $\mathrm{N}$ & B & $\mathrm{P}, \mathrm{S}$ \\
\hline 13 & Mavro Kalavriton & $\mathrm{L}$ & B & $\mathrm{P}, \mathrm{S}$ \\
\hline 14 & Mavro Kolliniatiko & $\mathrm{L}$ & B & $\mathrm{P}$ \\
\hline 15 & Mavro Siriano & $\mathrm{N}$ & B & $\mathrm{C}, \mathrm{P}$ \\
\hline 16 & Mavro Spetson & $\mathrm{L}$ & B & $\mathrm{C}, \mathrm{P}$ \\
\hline 17 & Mavroudi Voulgarias & $\mathrm{N}$ & B & Thr \\
\hline 18 & Papadiko & $\mathrm{N}$ & B & I \\
\hline 19 & Pappoudes & $\mathrm{N}$ & B & Th \\
\hline 20 & Vlachiko & $\mathrm{L}$ & B & $\mathrm{E}, \mathrm{Th}$ \\
\hline 21 & Voulgaroudes & $\mathrm{N}$ & $\mathrm{B}$ & - \\
\hline
\end{tabular}

a: Transliteration of the original Greek name of cultivar into Latin characters

b. Ampelographic collection N: Institute of Viticulture (NAGREF, Lykovrysi, Athens), L: Laboratory of Viticulture (AUA, Athens)

c. B: black/red, Rs: pink

d. A:Attica, C:Cyclades, D:Dodecanese, E:Epirus, I:Ionian Islands, M:Macedonia, P:Peloponnese, S: Sterea Ellada, Th: Thessaly, Thr: Thrace 
Table 2. Primers combination used for AFLP analysis

\begin{tabular}{cc}
\hline $\begin{array}{c}\text { Primer Code } \\
\text { EcoRI-Axx (Dye) }\end{array}$ & $\begin{array}{c}\text { Primer Code } \\
\text { MseI-Cxx }\end{array}$ \\
\hline EcoRI - ACA (FAM) & MseI - CTA \\
EcoRI - ACA (FAM) & MseI - CTC \\
EcoRI - ACT (FAM) & MseI - CAT \\
EcoRI - ACG (JOE) & MseI - CAC \\
EcoRI - ACG (JOE) & MseI - CTA \\
EcoRI - AGG (JOE) & MseI - CAG \\
EcoRI - AGG (JOE) & MseI - CAT \\
\hline
\end{tabular}

used to evaluate the most important parameters that contributed to the grapevine cultivar separation into different groups according to their morphological traits (OIV descriptors).

For the statistical analysis of the ampelographic and the molecular data, the method UPGMA was used with one dissimilarity / distance coefficient and one similarity coefficient, respectively. In order to present the morphological relationships between the cultivars, the Euclidean Distances Squared distance coefficient was used, as implemented in the NTSYS-pc package 2.1 developed by Rohlf (Exeter Software, New York, USA, 1993). For the molecular analysis, the degree of genetic similarity (I) detected between each pair of cultivar studied was calculated using the Simple Matching (SM) coefficient (Sneath and Sokal, 1973) as implemented in the NTSYS-pc package 2.1.

\section{Results and Discussion}

\section{OIV Ampelographic Descriptor Evaluation}

According to the PC analysis, which transforms the original data set (OIV descriptors) into a smaller set of uncorrelated new variables (Principal Components, where eigenvalues was bigger than 1), nine (9) components have been produced in a decline series of their importance, explaining $86.9 \%$ of the total variability among the different cultivars. All descriptors that are grouped in the same principal component have strong correlation between them. Each component is strongly correlated with a set of the initial OIV descriptors so it could be estimated their contribution to variability. The OIV descriptors strongly correlated with the first 9 components are presented in Table 3 and Fig. 1. For example, and for the cultivars studied, the OIV descriptors 084 (Mature leaf: density of prostrate hairs between the main veins on lower side of blade), 004 (Young Shoot: density of prostrate hairs on tip), 053 (Young leaf: density of prostrate hairs between main veins on lower side of blade (4th leaf)), 079 (Mature leaf: degree of opening / overlapping of petiole sinus) contributed better to variability compared to OIV descriptors 067 (Mature leaf: shape of blade), 208 (Bunch: shape), 080 (Mature leaf: shape of base of petiole sinus), 014 (Shoot: density of prostrate hairs on internodes), 075 (Mature leaf: blistering of upper side of blade).

Cluster analysis separated the varieties in particular groups according to their morphological characteristics. The main group includes the grape varieties which exhibit morphological traits typical of the Vitis vinifera proles pontica, sub-proles balcanica (Negrul, 1938; Levadoux, 1956), while cultivar 'Karabraimis', which is characterized by sparsely distributed prostrate hairs on shoot tips, shiny young leaves, mostly glabrous when fully expanded, and clusters with medium to large berries, as are the traits of the proles orientalis (Negrul, 1938; Levadoux, 1956), is grouped in a different branch of the dendrogram. The data from the ampelographic description with the 29 ampelographic descriptors of the varieties studied (Appendix A) were used to create a distance matrix in order to generate a dendrogram (Fig. 2), discriminating all samples studied.

As shown in Fig. 2, (a) cultivars 'Mavrostifo', 'Mavro Arachovis', 'Mavro Kolliniatiko', 'Mavrokorakas', 'Mavro Spetson', 'Kountoura mavri', 'Pappoudes', 'Karvouniaris', 'Mavroboubouko', 'Mavro Siriano', 'Papadiko', and 'Vlachiko', are located in the main cluster of the dendrogram. These cultivars, besides their morphological similarities, are of the same viticultural centers of Peloponnese and western Greece. 'Kountura mavri', 'Mavro Spetson' and 'Pappoudes' have the smallest distance between them, indicating that they are closely related cultivars which may have originated by the same parent variety through the accumulation of mutations. (b) Cultivars 'Kartsiotis', 'Agiomavritiko' and 'Gaidouricha' are grouped in the same brunch of dendrogram, with relatively small distances between them, especially between the first two. Cultivars 'Agriomavritiko' and 'Gaidouricha' are considered indigenous to the Ionian islands and are sporadically cultivated in Thessaly, where cultivar 'Kartsiotis' is also cultivated. (c) 'Mavroudi Voulgarias', 'Voulgaroudes', 'Mavro Arachovis' and 'Mavro Kalavriton' have large distances indicating that they are completely different cultivars and (d) Finally, cultivars 'Mavroliatis' and 'Mavrotragano' are grouped in the same brunch due to low density of hairs on the leaves and shoot.

\section{Molecular analysis}

For the molecular analysis and the identification of the cultivars studied, seven primer combinations were used to amplify genomic DNA from the twenty-one Greek grapevine cultivars. They proved to be highly polymorphic and produced a total of more than 590 amplified fragments (Table 4) and the related electrophoregrams (Appendix B), discriminating all the samples studied. The molecular analysis data were then used to obtain a genetic similarity dendrogram (Fig. 3).

The data from the molecular analysis show that there is genetic variation between the cultivars studied and the degree of this variation differs depending on the various groups and their origin, confirming to a certain extent the results of the ampelographic description.

Cultivars 'Kountoura mavri', 'Mavro Spetson' and 'Pappoudes' are closely related and the high degree of genetic

Table 3. Evaluation of the OIV descriptors and their contribution to the variability of the cultivars studied

\begin{tabular}{|c|c|c|c|c|c|c|c|c|}
\hline \multicolumn{9}{|c|}{ Principal Components } \\
\hline 1 & 2 & 3 & 4 & 5 & 6 & 7 & 8 & 9 \\
\hline \multicolumn{9}{|c|}{$\%$ Contribution to variability } \\
\hline 20.86 & 15.20 & 12.19 & 9.16 & 7.51 & 7.00 & 5.85 & 4.96 & 4.18 \\
\hline \multicolumn{9}{|c|}{ Eigenvalue } \\
\hline 5.00 & 3.64 & 2.92 & 2.19 & 1.80 & 1.68 & 1.40 & 1.19 & 1.00 \\
\hline \multicolumn{9}{|c|}{ Related OIV descriptors } \\
\hline 084 & 086 & 070 & 076 & 206 & 223 & 204 & 003 & 067 \\
\hline 004 & 082 & 102 & 068 & 087 & 101 & 225 & 051 & 208 \\
\hline 053 & 065 & & & & & & & 080 \\
\hline \multirow[t]{2}{*}{079} & & & & & & & & 014 \\
\hline & & & & & & & & 075 \\
\hline
\end{tabular}



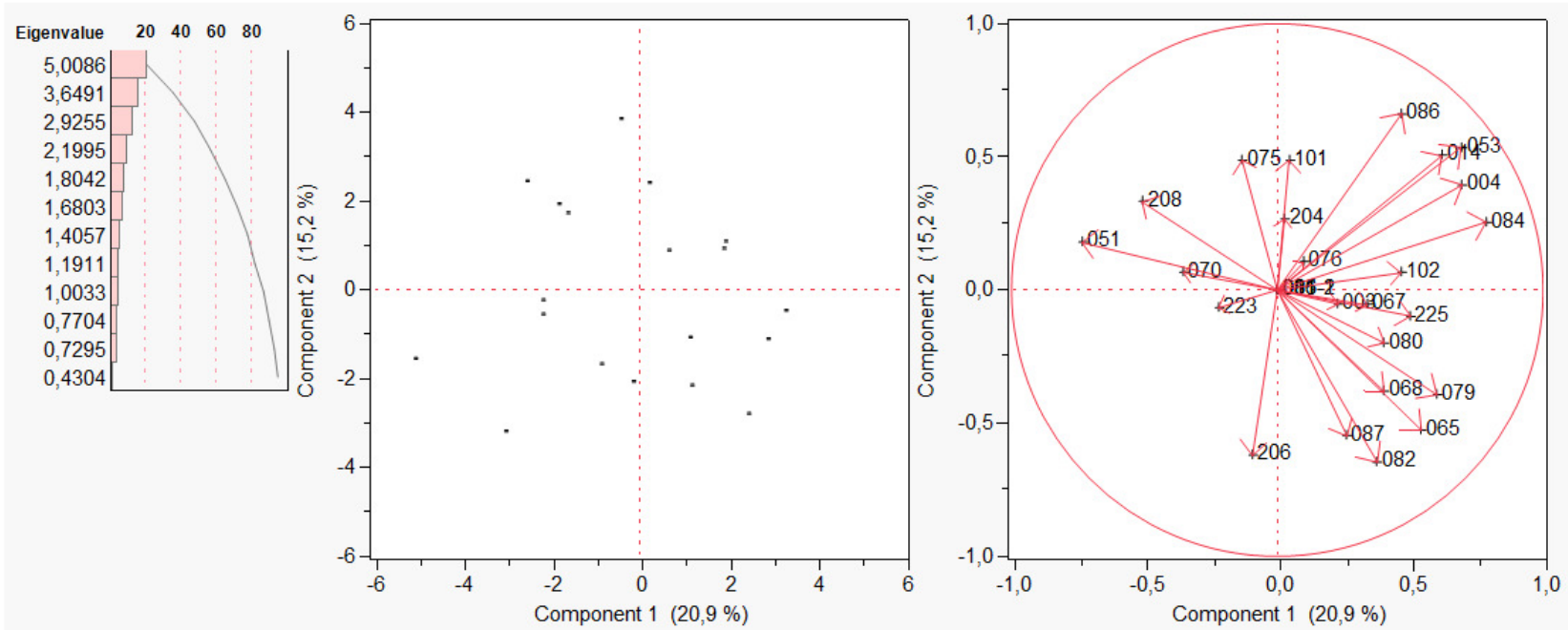

Fig. 1. Evaluation of the OIV descriptors and their contribution to the variability of the cultivars studied

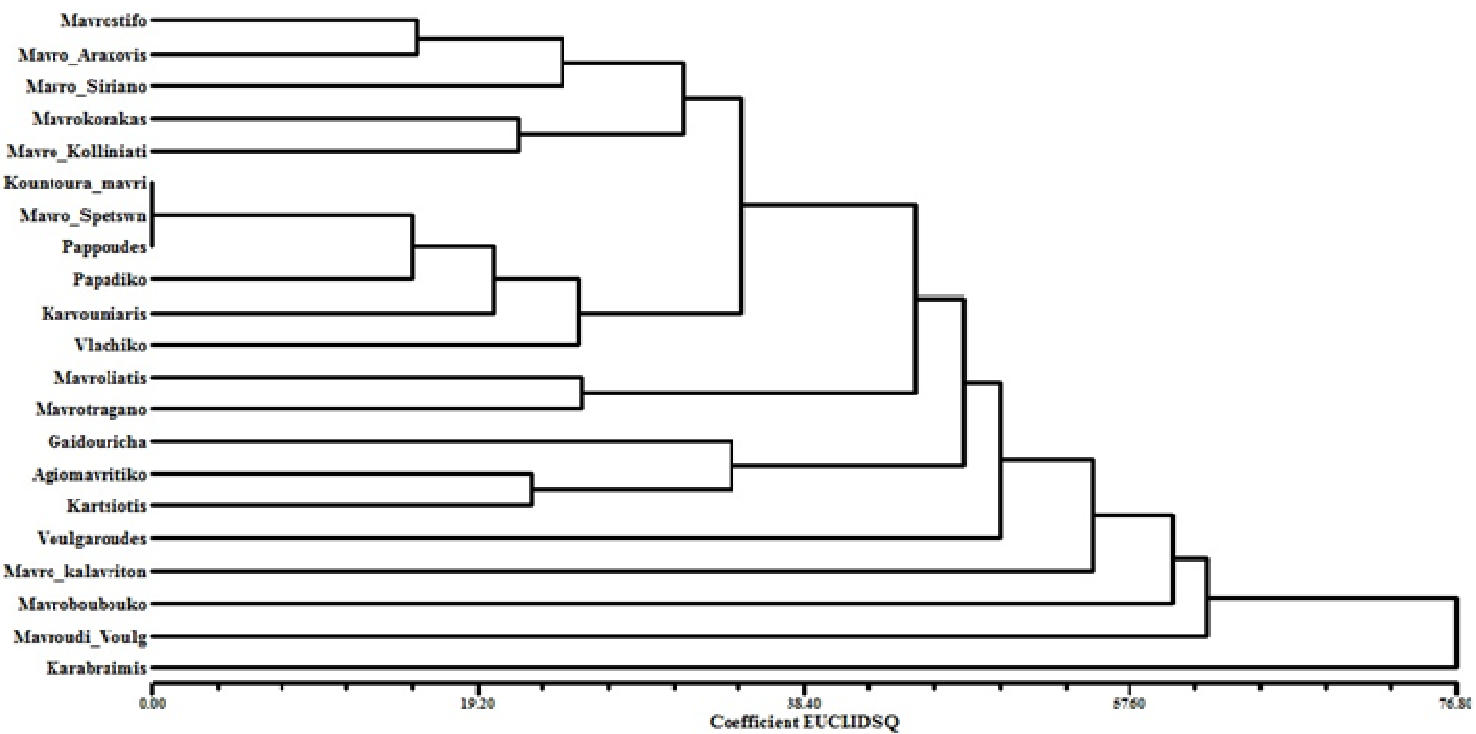

Fig. 2. Dendrogram based on ampelographic descriptors showing the relationship among samples studied (Dissimilarity Coefficient Euclidean Distances Squared, UPGMA)

Table 4. Primers used and number of amplified fragments

\begin{tabular}{cc}
\hline $\begin{array}{c}\text { Primer Code } \\
\text { EcoRI - Axx - Dye - Mse - Cxx }\end{array}$ & $\begin{array}{c}\text { Number of Amplified } \\
\text { Fragments }\end{array}$ \\
\hline EcoRI - ACA (FAM) - MseI - CTA & 126 \\
EcoRI - ACA (FAM) - MseI - CTC & 95 \\
EcoRI - ACT (FAM) - MseI - CAT & 38 \\
EcoRI - ACG (JOE) - MseI - CAC & 104 \\
EcoRI - ACG (JOE) - MseI - CTA & 80 \\
EcoRI - AGG (JOE) - MseI - CAG & 70 \\
EcoRI - AGG (JOE) - MseI - CAT & 81 \\
Total & $\mathbf{5 9 4}$ \\
\hline
\end{tabular}

similarity ( $\mathrm{I}=0.95$ and $\mathrm{I}=0.93$ between 'Kountoura mavri' with 'Mavro Spetson', and 'Pappoudes' respectively) allows the speculation that the last two are clones of the first. 'Kountoura mavri', as mentioned above, is considered a clone or synonym of the very old red wine cultivar 'Mandilaria' (Krimbas, 1943; Stavrakaki and Stavrakakis, 2017). A recent study by means of the SSR molecular method showed that cultivars 'Kountoura mavri' and 'Mouchtaro' (which is also considered a clone or 


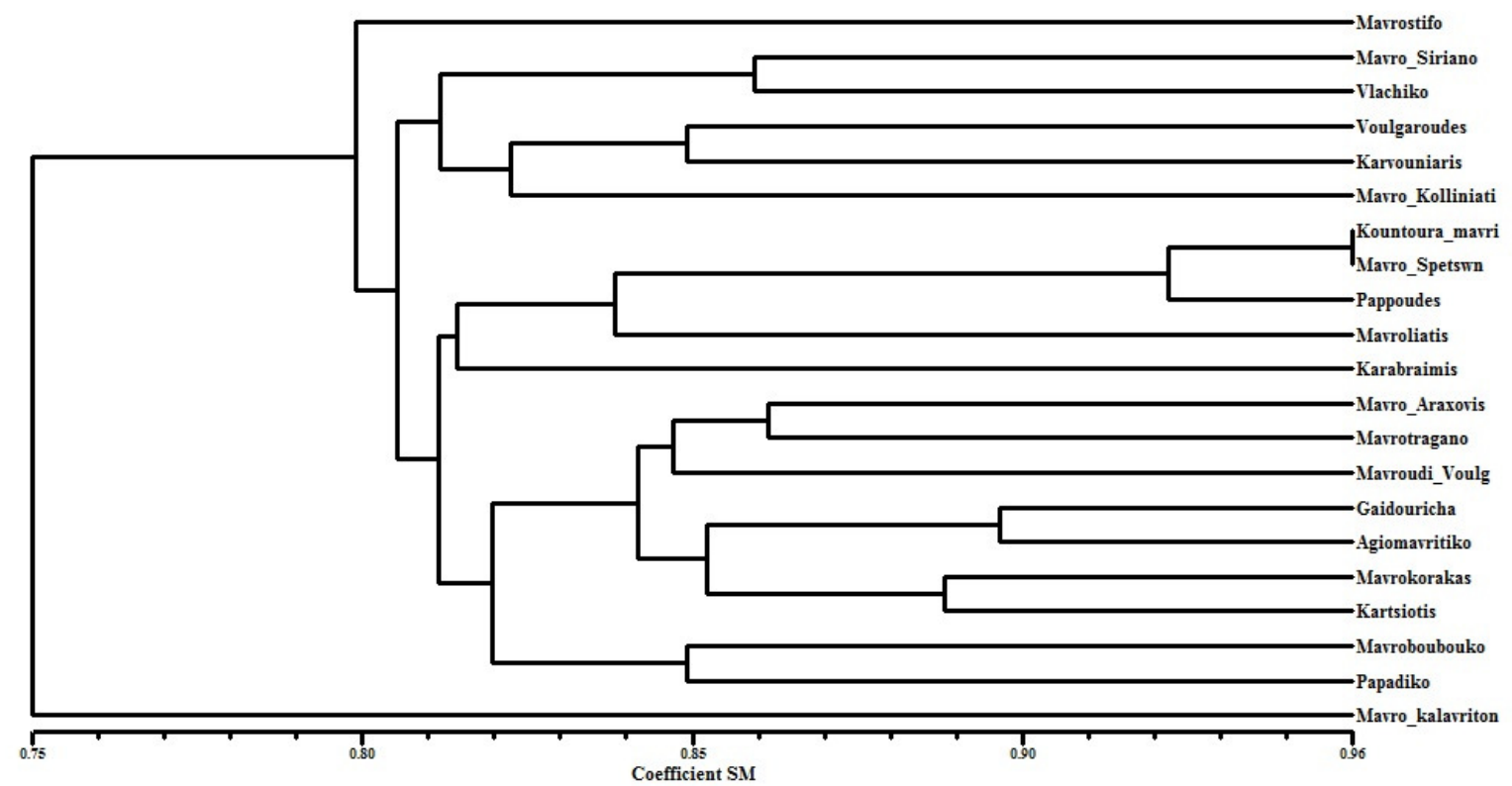

Fig. 3. Dendrogram based on AFLP amplification products showing the relationship among samples studied (Similarity Coefficient Simple Matching, UPGMA)

The highest values were observed with 'Agiomavritiko' ( $\mathrm{I}=0.86)$, 'Mavrotragano' (I=0.86), 'Mavrokorakas' ( $\mathrm{I}=0.85$ ) and 'Mavroudi Voulgarias' ( $\mathrm{I}=0.84$ ), while the lowest value was observed with cultivar 'Mavro Kalavriton' (I=0.76). Despite the high degree of genetic similarity, grapevine cultivar 'Mavro Arachovis' is closely related to the above cultivars, but in fact, they are different cultivars. This is also true for cultivars 'Mavroudi Voulgarias' and 'Voulgaroudes'. These data, and especially for cultivars 'Mavro Arachovis' and 'Mavroudi Voulgarias', confirm the results of previous studies with the use of molecular method SSR (Hvarleva et al., 2004). At the same time, grapevine cultivar 'Karvouniaris', which is one of the most well-known and widespread 'Mavroudia' of Peloponnese, showed relatively high degree of genetic similarity with 'Voulgaroudes' ( $\mathrm{I}=0.85$ ) and 'Mavro Kolliniatiko' ( $\mathrm{I}=0.83$ ).

The high degree of genetic similarity particularly between the pair 'Gaidouricha' - 'Agiomavritiko' (I=0.90) shows that they most likely originated from the same parent variety through the accumulation of mutations. This may also be true for cultivars 'Mavrokorakas' and 'Kartsiotis' ( $\mathrm{I}=0.89)$, but in a smaller degree of probability.

Relatively high degree of genetic similarity was found between the pairs 'Mavroboubouko' - 'Agiomavritiko' (I=0.854), 'Mavroboubouko' - 'Papadiko' ( $\mathrm{I}=0.852$ ) and 'Mavroboubouko' - 'Gaidouricha' ( $\mathrm{I}=0.835)$. As mentioned earlier, cultivars 'Mavroboubouko' and 'Papadiko' are cultivated in Zante and the cultivar that is locally called 'Agiomavritiko' (Zante) is most likely their biotype or synonym. All these cultivars may have derived from one initial and still unknown old wine grape cultivar.

\section{Conclusions}

The present study verifies the indispensable role of the ampelographic description when it comes to studying old and polyclonal grapevine cultivars with many synonyms, homonyms and variants, as is the case in the group of 'Mavroudia' in Greece. The ampelographic description, according to the OIV descriptor list and especially when it takes place for at least three consecutive years, in combination with molecular methods can constitute reliable tools for the discrimination of grapevine cultivars, clones and biotypes. In the case of 'Mavroudia' and given the large number of the varieties, the different biotypes, clones, synonyms and homonyms, the precise ampelographic determination of the samples studied is deemed necessary.

\section{Acknowledgements}

This research received no specific grant from any funding agency in the public, commercial, or not-for-profit sectors.

\section{References}

Alba V, Anaclerio A, Gasparro M, Caputo AR, Montemurro C, Blanco A, Antonacci D (2011). Ampelographic and molecular characterization of Aglianico Accessions (Vitis vinifera L.) collected in Southern Italy. South African Journal of Enology and Viticulture 32(2):164173.

Anhalt UCM, Martinez SC, Rühl E, Forneck A (2011). Dynamic grapevine clones - an AFLP-marker study of the Vitis vinifera cultivar Rieslingcomprising 86 clones. Tree Genetics \& Genomes 7:739-746.

Applied Biosystems (2007). AFLP Plant Mapping Protocol. Foster City, California USA

Baillod M, Baggiolini M (1993). Les stades repères de la vigne. Revue Suisse de Viticulture Arboriculture Horticulture 25:7-9.

Biniari K, Stavrakaki M (2016). Is grapevine cultivar 'Korinthiaki Staphis' a mutation of grapevine cultivar 'Liatiko'? Geotechnical Scientific Issues, Geotechnical Chamber of Greece (in press).

Biniari K, Stavrakakis MN (2013). The 'vine of Pafsanias' and the group of grape cultivars 'Mavroudia' of the vineyard of Peloponnese. In: Proceedings of Ampelos 2013,3rd International Symposium Trends in world vitiviniculture development', 30-31 May 2013, Santorini Island, Greece. 
Blaich R, Konradi J, Ruhl E, Fomeck A (2007). Assessing genetic variation among Pinot noir (Vitis vinifera L.) clones with AFLP markers. American Journal of Enology and Viticulture 58(4):526-529.

Davidis OX (1967). Greek Ampelology (in Greek). Band 3, Elements of Ampelography. Athens.

Fanizza G, Lamaj F, Resta P, Ricciardi L, Savino V (2005). Grapevine cvs Primitivo, Zinfandel and Crljenak kastelanski: molecular analysis by AFLP.Vitis 44:147-148.

Gennadios P(1895). Botany Lexicon (in Greek). Athens.

Guillon JM(1896).Les cépages orientaux. G. Carre. Paris.

Harvalia A (1961). Différenciation des vins des hybrids et des cépages de la vigne européenne par chromatographie sur papier (in Greek). Chroniques Chimiques 26A:180-187.

Hvarleva T, Rusanov K, Lefort F, Tzvetkov I, Atanassov A, Atanassov I (2004). Genotyping of Bulgarian Vitis vinifera L. cultivars by microsatellite analysis. Vitis 43:27-34.

Imazio S, Labra M, Grassi F, Winfield M, Bardini M, Scienza A (2002). Molecular tools for clone identification: the case of the grapevine cultivar 'Traminer'. Plant Breeding 121:531-535.

Krimbas V (1943). Greek Ampelography (Vol. I) (in Greek). Ministry of Agriculture, Athens, Greece.

Krimbas V (1944). Greek Ampelography (Vol. II) (in Greek). Ministry of Agriculture, Athens, Greece.

Krimbas V (1949). Greek Ampelography (Vol. III) (in Greek). Ministry of Agriculture, Athens, Greece.

Levadoux LD (1956). Wild and cultivated populations of Vitis vinifera $\mathrm{L}$. Annales del'Amélioration des Plantes 6:59-118.

Logothetis BX, Vlachos M (1966). Ampélographie Hellénique (in Greek). Annuaire de la Faculté Agronomique de l'Université de Thessaloniki 377-392.

Meneghetti S, Costacurta A, Morreale G, Calò A (2012). Study of intravarietal genetic variability in grapevine cultivars by PCR-derived molecular markers and correlations with the geographic origins. Molecular Biotechnology 50:72-85.

Merkouropoulos G, Michailidou S, Alifragkis A, Zioziou E, Koundouras S, Argiriou A, Nikolaou N (2015). A combined approach involving ampelographic description, berry oenological traits and molecular analysis to study native grapevine varieties of Greece. Vitis 54:99-103.

Molon G(1906). Ampelografia (Vol. II).Ulrico Hoepli, Milano.

Myles S, Boyko AR, Owens CL, Brown PJ, Grassi F, Aradhya MK, ... Buckler ES (2011). Genetic structure and domestication history of the grape. Proceedings of the National Academy of Sciences USA 108(9):3530-3535.

Negrul AM (1938). Evolution of cultivated forms of grapes. Comptes Rendus del'Académie des Sciences, USSR 18:585-588.
OIV (2009). OIV Descriptor List for Grape Varieties and Vitis Species, 2nd ed. Organisation Internationale de la Vigne et du Vin. http://www.oiv.int/oiv/info/enplubicationoiv.

Palaiologos Gr (1836). On Viticulture andEnology (in Greek). Athens.

PoniropoulosE(1888). Viticulture andEnology (in Greek). Athens.

Pulliat V (1888). Mille variétés de vignes. Description et synonymies, 3ème ed., Coulet, Montpellier.

Robinson J, Harding J, Vouillamoz J (2012). Wine Grapes. A Complete Guide to 1,368 Vine Varieties, including their Origins and Flavours. London: Allen Lane(Penguin) and New York: Ecco (HarperCollins).

RohlfFJ (1993). NTSYS-pc. Numerical taxonomy and multivariate analysis system(Version 2.0.2i). Exeter Software, Setauket,New York.

Shinde MP, Upadhyay A, Aher LB, Karibasappa GS (2013). Molecular marker analysis to differentiate a clonal selection of Centennial Seedless grapevine. African Journal of Biotechnology 12(14):15941597.

Sneath PH, Sokal RR (1973). Numerical taxonomy. The principles and practice of numerical classification. Freeman W.H. and Company, San Francisco and London.

Stavrakaki M, Biniari K (2016). Genotyping and phenotyping of twenty old traditional Greek grapevine varieties (Vitis vinifera $\mathrm{L}$.) from Eastern and Western Greece. Scientia Horticulturae 209:86-95.

Stavrakaki M, Stavrakakis MN (2017). The Cretan Grapes. Tropi Publications. Athens.

Stavrakakis MN (1981). Identification of grape cultivars (Vitis vinifera $\mathrm{L}$.) by pollen isozyme polymorphisms. $\mathrm{PhD}$ Thesis. Agricultural University of Athens. Athens.

Stavrakakis MN (1990). Comparative study of grape cultivars of the 'Mavroudia' group (in Greek). Agricultural Research 14:19-29.

Stavrakakis MN, Stavrakaki M, Biniari K, Bouza D (2017). Ampelography of the forgotten Greek grapevine cultivars (in Greek). Tropi Publications. Athens (in press).

StenkampSHG, Becker MS, Hill BHE, Blaich R, Fomeck A (2009). Clonal variation and stability assay of chimeric Pinot Meunier (Vitis vinifera $\mathrm{L}$.) and descending sports. Euphytica 165:197-209.

Thomas MR, Matsumoto S, Cain P, Scott NS (1993). Repetitive DNA of grapevine: classes present and sequences suitable for cultivar identification. Theoretical Applied Genetics 86:173-180.

Viala P, Vermorel V (1909). Traité Général d'Ampélographie(Volumes 7). Maison éd, Paris.

Vignani R, Scali M, Masi E (2002). Genomic variability in Vitis vinifera L. "Sangiovese" assessed by microsatellite and non-radioactive AFLP test. Electronic Journal of Biotechnology 5(1):1-11.

Vlachos M(1986).Ampelography (in Greek). Thessaloniki.

Vos P,Hogers R, Bleeker M, Reijans M, Van deLeeT,Home M,Zabeau M (1995). AFLP: A new technique for DNA fingerprinting. Nucleic Acids Research 23:4407-4414. 